- felt for some time. Joseph Onek, for example, the lawyer for both Imanishi-Kari and Baltimore, says that the appeals board's ruling is a "great thing for Dr Imanishi-Kari, but $I$ also think it is a great thing for science". He adds: "I hope that this case will now lead the government and scientific community to reassess how these scientific misconduct disputes are handled, and try to figure out ways to resolve them more promptly and fairly."

ORI, never popular among scientists, is now likely to lose even more support. Indeed, the heaviest criticism in the appeals board's ruling was levelled at the integrity office, saying that much of the evidence it presented was "irrelevant, had limited probative value, was internally inconsistent, lacked reliability or foundation, was not credible or not corroborated, or was based on unwarranted assumptions".

The appeals board ruling comes at a time when proposed new scientific misconduct regulations are being hotly debated both within DHHS and in the scientific community at large. How the department should respond to a congressionally mandated report on scientific misconduct is being considered by Shalala and her staff (see Nature 639, 381; 1996 and previous page).

In addition to ORI, another likely casualty of the appeals board ruling is O'Toole, now a researcher at the Genetics Institute, a private biotechnology company in Cambridge, Massachusetts. "The [board] has had the same initial reaction everybody has had: they can't believe that what I said happened, did in fact happen," says O'Toole. "But since they have tossed out the evidence, their conclusions are not surprising."

The appeals board called O'Toole's interpretations of some events "improbable and unwarranted", and parts of her testimony "not credible". But O'Toole takes issue with such statements. "From the beginning, I have always told the truth, with the full expectation I would be branded a liar for doing so," she says. "The miracle was that, without exception, every scientist who examined the evidence, eventually - and reluctantly - came to the conclusion I was telling the truth."

The panel said it was important that for 'whistleblowers' to be protected from adverse consequences. But it also warned that they should not get too heavily involved in a subsequent investigation. "Such involvement can compromise both the ability of the investigators to maintain objectivity, and the ability of the whistleblower to avoid becoming too vested in the outcome," it says. "We think that happened here."

Imanishi-Kari says that her first priority now is to seek reinstatement of her faculty position at Tufts University, a request which is likely to be granted by the university, which has been "very supportive" through the whole affair. "Then I will be back to the usual," she says. "Trying to get funding for my research."

Fintan Steele

\title{
Italian minister promises to cut research bureaucracy
}

Rome. Luigi Berlinguer, Italy's new research and education minister, promised last week that research will be one of the new government's highest priorities - even though pre-election pledges of increased funding may have to wait for improvements in the economy.

After one month in office, Berlinguer says he is keen to increase the cost-effectiveness with which Italy spends its research budget, in particular by requiring its notoriously bureaucratic research and university systems to increase their efficiency.

But he wants to do this as far as possible without introducing new laws into

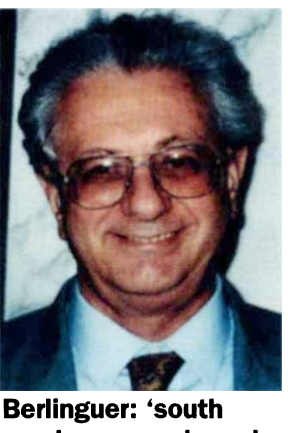

needs more science' areas which, he says,

already suffer from excessive legislation. At the same time, Berlinguer plans to introduce radical changes to the recruitment of university faculty members, raise support for scientists in the relatively impoverished south of Italy, and push for increased joint research funding by the European Union (EU).

Berlinguer is a member of the Democrat Party of the Left (PDS) - the successor to the former communist party - with long parliamentary experience. He was even made research minister in Carlo Ciampi's interim government in 1993, but his appointment lasted only a few hours before the PDS pulled out of the government.

One of his major targets, he says, is Italy's National Research Council (CNR), which funds around 350 research institutes and university centres. Scientists have long been frustrated by extensive delays in allocating CNR funds, and what they claim to be a general mismanagement of resources.

Many argue that the roots of such problems lie in the highly centralized organization that has existed since the research body was first established by Benito Mussolini in the early 1920s. Berlinguer says that he plans to push for the full implementation of a law drawn up at the end of the 1980 s by Antonio Ruberti, the former research minister, giving institutes sufficient autonomy to make their own internal regulations and control their own budgets.

At the same time, he plans to speed up grant review processes and simplify administrative procedures carried out through CNR's central headquarters, where staff numbers will be cut by relocating administrative positions to individual institutes.

A similar approach will be taken to the
CNR's 15 scientific advisory committees, which Berlinguer says are both too numerous and too large. Broader reform of the committee system, which would require an act of parliament, may follow later.

One area where he is already planning legislative action is reform of the controversial system of appointing university staff through national competitions - or concorsi - widely criticized for giving considerable weight to the personal connections of candidates (see Nature 378, 228; 1995).

Attempts by previous ministers to change the system have been unsuccessful, largely because of resistance from parliamentary professors who have themselves benefited from it. Although the parliament is still dominated by university professors, Berlinguer - who is himself professor of law at the University of Siena - hopes that fresh blood will judge more favourably his own radical reform proposals, the details of which will be announced shortly.

Another of Berlinguer's priorities is to find ways of recruiting more young scientists in southern Italy, where the proportion of researchers in the population is six times lower than in the industrialized north.

Various programmes to improve the science base of the south have been introduced by previous governments over the past few years, but he says that there is little to show for the IL1,000 billion (US\$640 million) invested so far. "The idea that money could be rained down on the south and that would be enough to make things work was ill-conceived. In future, it must be clear that the infrastructure is there to support research programmes."

The programmes will be relaunched, but with more checks and controls to ensure that investments are better protected. In addition, says Berlinguer, a recruitment drive will be introduced for young scientists, offering a large number of scholarships and temporary research contracts.

Even though Italy cannot afford to raise its relatively low level of investment in research - despite being the fourth largest economy in Europe, it spends only 1.3 per cent of its gross national product on research and development, barely half that of many other European countries - it will still propose an increase in the EU's fifth Framework programme of research, which will run from 1998 to 2002 .

Berlinguer justifies this on the grounds that Europe can only compete effectively with Japan and the United States if member states join forces as extensively as they can, although others point out that Italy would hope to be a net beneficiary of any increased spending on Framework.

Alison Abbott 